\title{
THE ART AND POLITICS OF ARTISTS' PERSONAS: THE CASE OF YAYOI KUSAMA
}

\author{
SOOJIN LEE
}

\begin{abstract}
This essay presents persona as a trajectory of contemporary art in the postindustrial art world, in which artists' "work" increasingly includes non-art activities such as networking and media publicity. After discussing pressing issues in art scholarship in regards to the disciplinary tradition and persona studies, I analyse the image of the Japanese artist Yayoi Kusama (b.1929) who has been operating in the Western-dominated international art world since the 1960s. Arriving in the U.S. in 1957, Kusama quickly became one of the most prolific and notorious artists in New York. However, by the early 1970s she returned to Japan and has since been living voluntarily in a psychiatric hospital. Art historical assessments of Kusama's work have generally been confined within the Western theoretical parameters of feminism and psychoanalysis. Here, I draw attention to her persona: a "non-art" topic that has largely been ignored within the modernist discipline of Art History, which insists on an object-based formalist methodology. I critique this tendency by demonstrating how an artist's persona can become a medium of art and politics, and how an artist's artworks can become by-products of the artist's larger-than-life public persona. I trace Kusama's effort at persona cultivation from New York in the early 1960s, and particularly explore her satirical and ironic use of the cultural, racial, and gendered stereotypes about Japanese women. Based on archival research and aesthetics analysis, I argue that Kusama exploited the commercial value of her Japanese body and identity at a time when escalating Cold War national pride and xenophobia jeopardised her career in New York. By discussing how she pursued selfpromotion and commercial success, this paper also portrays the commercialization of art and artists during the 1960s.
\end{abstract}

\section{KEY WORDS}

Yayoi Kusama; artist's persona; art history; artist as celebrity; Orientalism

\section{INTRODUCTION}

In 2012, the Japanese artist Yayoi Kusama (b. 1929) had the largest retrospective exhibition of her career, co-organised by the Tate Modern in London and the Whitney Museum of American Art in New York. In conjunction with the exhibition, the English translation of her autobiography was published, nine years after its initial publication in Japanese. Moreover, the French luxury fashion brand Louis Vuitton, a subsidiser of the exhibition, launched a collection of clothes and accessories, all printed with Kusama's autographical dots. To celebrate and advertise the limited collection, Louis Vuitton's flagship stores worldwide were decorated with "avatars" of Kusama-her lifelike mannequins, all wearing her trademark dotted dress and red wig, as well as her trademark motifs such as dots, flowers, and dotted plant forms. Not a mere 
presentation of art, this multilateral exhibition event pronounced a few significant but underdiscussed facts and questions about Kusama and the contemporary art system. First, the flamboyant display of "Kusamas" in the mass-culture marketing indicates that the artist has successfully cultivated a unique and profitable persona. Second, her persona needs to be analysed, especially since it has become an art itself and Kusama a remarkable celebrity. Third, the art world is not unlike other creative industries such as film, music, and fashion in that it produces its own stars and celebrities. But, fourth, commercial and mass culture topics continue to be rare and underestimated in scholarly discourses of art and artist, which I think results in part from the paucity of such concerns in the theoretical and methodological parameters of the modernist academic conventions of the Art History discipline.

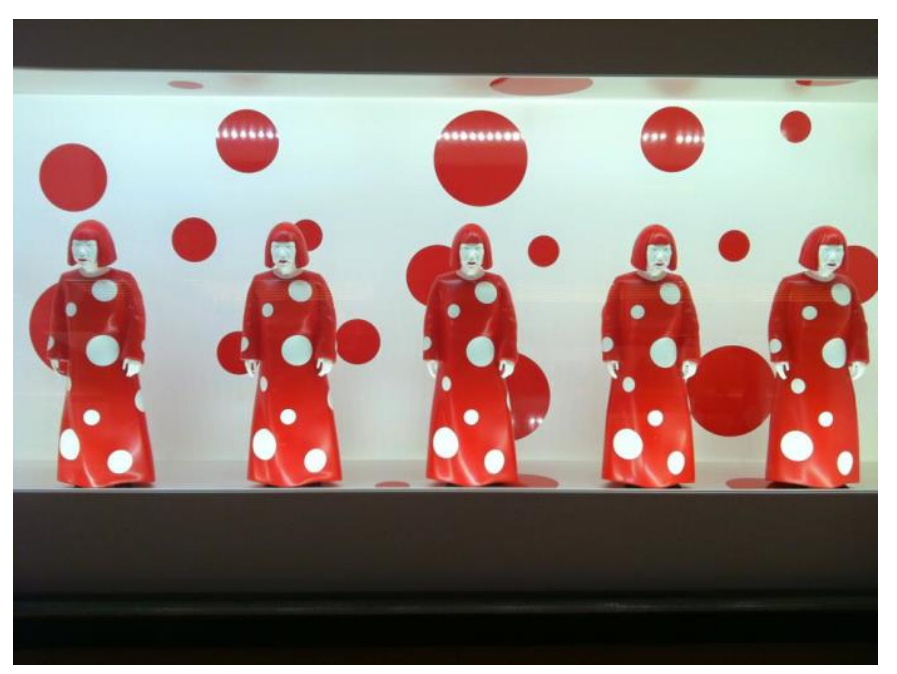

Fig 1: Louis Vuitton New York SoHo store display in Aug. 2012. Photograph by the author.

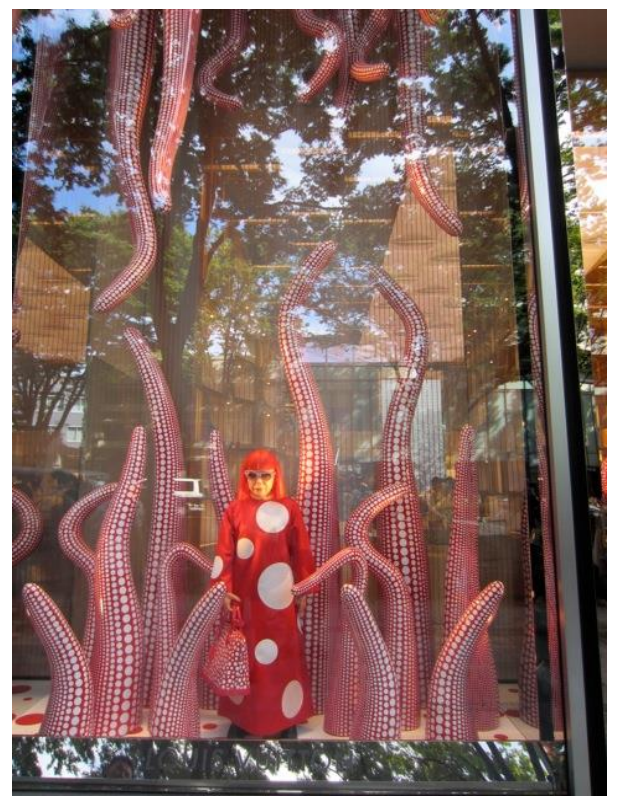

Fig 2: Louis Vuitton Tokyo Omotesando store window display in Aug. 2012. Photograph by David Novak. 
This essay presents persona as a trajectory of contemporary art in the post-industrial art world, in which artists' activities increasingly include non-art services such as networking and mass media publicity. After a discussion of pressing issues in art scholarship in regards to disciplinary tradition and persona studies, I will specifically analyse the image of Kusama that she gained while operating in the Western-dominated international art world since the 1960s. Kusama arrived in the United States in 1957 as one of the first postwar Japanese artists to move to New York City to pursue a career in the booming contemporary art scene, and her ambition and eccentricity quickly made her one of the most prolific and notorious artists in the city in the 1960s. But in the early 1970s she returned to Japan and has since been living voluntarily in a psychiatric hospital in Tokyo, where she continues to produce art. Art historical and theoretical assessments of Kusama's work of the 1960s germinated when the artist re-emerged on the international art scene in the 1990s. The writings by influential art critics and historians including Griselda Pollock (2000) and Mignon Nixon (2000) were in general confined within the Western theoretical parameters of feminism and psychoanalysis. While Kusama enjoyed the wave of the burgeoning literature and her growing popularity, she neither supported nor refuted such interpretations. She is well known for avoiding clear-cut explanations and definitions of her work, which further makes her a difficult subject of study in contemporary art history and journalism. But for the same reason, I would argue that her persona-and her effort at persona cultivation-demands a close analysis.

I will trace Kusama's effort at persona cultivation from New York in the early 1960s, and particularly explore her satirical and ironic use of the audience's cultural, racial, and gendered stereotypes about Japanese women. Based on archival research and aesthetics analysis, I argue that Kusama exploited the commercial value of her Japanese body and identity at a time when escalating Cold War national pride and xenophobia jeopardised her art career in New York. By discussing how she pursued self-promotion and commercial success, this analysis will also portray the commercialization of art and artists during the 1960s. Kusama actively and critically partook in what critical theorists such as Theodor Adorno and Max Horkheimer have described with concern as the conflation of art and entertainment in capitalist society. These are some of the "non-art" aspects that have been ignored within the modernist discipline of Art History, which insists on the object-based formalist methodology, while avoiding (or trying to avoid) the growing importance of the "world" outside of artworks, such as artists' biography and the art market's star system. I critique this tendency by discussing Kusama's case and demonstrating how persona can be a medium of art and politics, and how an artist's artworks can become byproducts of the artist's larger-than-life public persona.

\section{Persona Studies AND/In ART CRITICISM: Conceptual Clarifications}

To broach the significance of artists' personas and persona studies in art's scholarly dimensions, anthropological and sociological views of the art world can make useful bridges. Sociological theorists of art and artists, for example Janet Wolff, Pierre Bourdieu, Arnold Hauser, and Howard Becker, have challenged the traditional Kantian ideologies of artistic autonomy and have also discussed the social role and identity of artists. Also, anthropologists such as George Marcus and Fred Myers have aptly examined the art world as the "Western-centred tradition of fine arts that began with the birth of modernism and a transformed art market out of the previously dominant Academy system in nineteenth-century France" (3). Arguing against the prominent cynical view that "art worlds make art," Marcus and Myers proffered a belief in the individual agency of the artist as a social actor and suggest that scholars of art must consider ethnography in their research. Following that proposal, I am interested in how "non-Western" artists like Kusama have interacted with the modernistic, Euro-America-centric Western art world through the use of personas.

I propose to conceptualise artists' personas as sites of intercultural exchange and conflict between the artist and her socio-cultural context. Artists' personas can be analysed to make visible and elucidate the related landscapes of art (of the art world), culture (of the 
masses), and everyday life (of the individual participants), which are often separated in modernist art discourses or are taken for granted in contemporary art criticism. This conception of persona can be understood as similar to how architectural historian Esra Akcan conceptualises translation as both "a contact zone" and "a contested zone" that "not only makes cultural exchanges possible, but also reveals the tensions and conflicts created by the perceived inequalities between places" (4). Also, by emphasizing artists' use of personas, their own bodies, and performative tactics, we can empower artists as agents of creative production and its global circulation. As influential feminist cultural critics like bell hooks and Trinh T. Minh-ha have widely argued, women of colour have often been under-represented and/or caricatured in hegemonic Western cultures and media, but they can also transform the stereotypes by engaging critically and creatively with them in everyday practice of cultural politics.

Here I am not proposing to deconstruct or undermine the disciplines of Art History and Art Criticism with those of social sciences. But I am trying to share my struggle as an art historian with the former's philosophical disciplinary limitations, and demonstrate how it can be resolved by considering perspectives of other disciplines that are foreign to the Art History academia, for example, in this case dramaturgy and celebrity studies among others. In my experience of art history education in the United States of America, sociological discourses of art and artists were mostly overlooked while aesthetic concerns remained highlighted (if not dominant) in course readings and discussions.

However, it should be stated that to analyse the politics of public image is not a completely novel approach in art history scholarship. Cultural historians of Abstract Expressionism like Michael Leja (1993), Ann Gibson (1997), and Fionna Barber (2004) have explored the troubled existential subjectivity and the rebellious macho masculinity performed and embodied by the painter Jackson Pollock and other leading artists of the so-called New York School. Many art historians such as Max Kozloff (1973), Eva Cockcroft (1974), David and Cecile Shapiro (1977), and Serge Guilbaut (1985) have investigated the US government's use of Abstract Expressionism during the Cold War to propagate "American" ascendant consumerism, democracy, and individualism. Rarely, however, has the use of public image or the imagemaking strategy been explored in relation to East Asian artists who have thrived in America.

As an object of considerable study as described above, Pollock's image is interesting in that both the artist and the media coverage (including the famous Life magazine's in August 1949) were involved in the formation of his "free" and young "American" cowboy image which also matched the aesthetics of his drip paintings - a technique widely described as inspired by Navajo sand paintings. As a recent biographer of Pollock elaborates:

It wasn't his paintings alone, however, that Life made famous. Pollock ... was spectacularly photogenic. The Life article showed him leaning up in front of one of his paintings in jeans and a denim jacket, ankles crossed, arms crossed, cigarette dangling from his mouth; both the cocky pose he adopts and the expression on his face convey his defiance, his refusal to cozy up to the camera. He does not look like a civilized man; he looks dangerous and sexy, full of latent power: a cowboy, or a motorcycle hoodlum..... The very fact that his paintings had been made not with gentlemanly oils but with the sort of industrial paints used by builders and laborers was further proof of his toughguy status. This was no effete character in a smock and a beret; this was a portrait of the artist as America-and the rest of the world-had never seen him before (Toynton xiv$\mathrm{xv}$ ).

What is articulated here is the becomingness and conflation of Pollock's body image, his art, and his attitude, which altogether evoked the image of young and cool America. Such a troubled, rebellious macho masculinity of Pollock's persona prefigured (and may have inspired) those of the Hollywood actors like Marlon Brando and James Dean who would rise to stardom by playing antiheroes in movies like A Streetcar Named Desire (1951) and Rebel Without a Cause (1955). 
Another artist who cultivated a persona that matched the aesthetics of his artwork was Andy Warhol. Around the same time as he founded the Factory (his studio and soon-to-be New York's most desired hangout place) in 1962, Warhol also underwent a major makeover of his appearance (e.g., getting a nose job and changing dress style) and stylised his attitudes as well: "The new public Andy was the epitome of cool. With shades, striped T-shirts, leather trousers and pointed shoes, he was chilled 24/7-apparently too laid back or bored even to answer questions from the press. The essential ingredient of the new Andy Warhol persona was Andy the machine, Andy the android, Andy the asexual creature" (Andy Warhol). A cultural icon with a specific look, Warhol has been dramatised in numerous movies by actors including Jared Harris, Guy Pearce, and David Bowie, who played the role by wearing the pale face, the spiky silver wig, the lofty shyness, and the evasive manner, among other Warholian characteristics.

The term persona, when applied to public figures, usually refers to their public images or public "selves" performed or formed among the publics and in mass media. The recently growing discourses of persona studies, a field developed from media and celebrity studies, are inevitably concentrated on studying images of celebrities. An early prominent contributor to celebrity and persona studies, Janet Thumim's 1986 article on Katharine Hepburn's star persona, defined persona as "a public image which derives from the performances and utterances of the person and is constructed over time in specific ways" (71), stressing that the persona should be distinguished from the person and also implying that celebrities (unlike the above examples of Pollock and Warhol) have little control over their public images.

Yet, as noted with Pollock and Warhol's public images, there is another kind of "persona" at work in contemporary culture-the art star. In contemporary culture, where mass media play an influential role in identity management, an artist who gains exceptional media exposure can become a celebrity, and his/her artworks may come to look like by-products of his/her larger-than-life public persona. This is why autographs of artists like Pablo Picasso and Vincent van Gogh have their own values separately from their paintings. As art critic Carter Ratcliff has aptly described, in the institutionalised and capitalist art world, a big-name painter is like a brand or corporation, "a non-person that bears a person's name but for the sake of clarity must never be confused with that person" (106). Ratcliff continues: "When an artist achieves institutional status his or her self aggrandizes its scale and takes on the impersonality of an emblem. This institutional version of the self still displays characteristic personal traits, but they are now formulized, even conceptualized" (106). There may be little to no difference between the ways an art star operates and a pop star operates in contemporary systems of culture. But compared to a pop or movie star's persona, an artist's persona can be a far more complicated subject of discussion because a painter or sculptor is not readily received as a performer, and because the formation of an artist's image partakes his/her art objects (rather than embodied performances) as well. An artist's persona is often subtle, ironic, indiscernible, and less a thing of the public culture than that of pop or movie stars.

An artist's persona can be defined as a concrete but unstable body-image and a performative interface between a person's (internal) subjectivity and (external) identity which can reveal the complicated relations among performance, representation, and perception of those artists who have become symbolic figures in contemporary culture. Briefly put, I view an artist's persona as a performative category and method in visual culture studies that blurs not only the conventional art-historical separations of fine arts, media arts, and performing arts, but also the traditional boundaries between self and persona, between subject and object, between artist and the art, between producer and audience, between presentation and representation, between art and politics, and between art and commerce. My interdisciplinary approach to artists' personas utilises the following concepts about contemporary culture in their extended and intersecting definitions: art world, persona, and politics of celebrity.

Art world: While the art world has traditionally been seen as an exclusive network of people who share particular interests, knowledge, and language of art and aesthetics (e.g. 
Danto), because of its growing collaborations with and assimilation into commercial industries such as fashion, the contemporary art world is currently seen as a "creative industry" (Caves) or a "creative enterprise" (Buskirk). The contemporary art world, which is multimedia in its modes and methods of growth and existence, generates 'artist personas' - indefinable yet tangible images of the artists resulting from the published images of their works, their face and body, the accompanying texts, and the ensuing talks in the discursive spaces. This public identity of an artist can have psychological and commercial influences—at least distantly-on the artist's inner self as well as on the perceptions and receptions of her works.

Persona: Authoritative theorists of persona such as Carl Jung and Erving Goffman have rendered life as a series of role-playing performances and have also emphasised the collaborative nature of persona formation resulting from the needs of the society. According to Goffman, one's social life (which he described as a "theatre" in which s/he performs different roles) is a "relatively closed system," limited by social norms, and that human interaction is "the reciprocal influence of individuals upon one another's actions" (15). This means that stereotypes, assumptions, and prejudices are thus inevitable in social interactions and identity formations. This is why personas can be used to trace the society's dominant desires and discourses of identity. An artist's persona, which operates in any cultural sphere, is formed out of his/her social relations as well, and may therefore also mirror and reveal the society and culture's collective myths and their dominant notions of identity.

Celebrity persona: As we have seen above, some artists manage to become celebrities and/or cultural icons, and their personas can be and should be analysed for their historical, cultural, or social significance. Assuming that collective desires are involved with their success and fame or notoriety, I read the artist's persona as a cultural and performative text, and so analyse what P. David Marshall (2006) describes as "the textual and extra-textual dimensions of the public persona" (9). According to Marshall, a celebrity's persona is textual because s/he performs on-screen or on-stage roles that are constructed by the industry and are thus themselves cultural and ideological texts; but it is also extra-textual because s/he can always present oneself differently in off-screen and off-stage performances (for example, in interviews, talk show appearances, and "real-life" photographs by paparazzi) and because what other people (audiences and critics) say or write about him/her also contribute to his/her image. Celebrity studies' methodology is extensive by nature, and in this essay about art and artist, I propose and demonstrate that art history can likewise take a synthetic approach of analysis by looking at both art and non-art images of artists and their works and activities.

\section{KASUMA'S STRUGGLE FOR RECOGNITION}

Kusama is one of the most puzzling personas in contemporary art. As mentioned, she has entered herself into a psychiatric hospital and she does not like to explain in depth about her artworks. But interestingly she abandons her reserve only when speaking of her mental struggle, which she uses to explain her originality as an artist. She has famously claimed that her art's reoccurring motifs and themes like dots, nets, flowers, obsession, and repetition derive from her continuous hallucinations developed during her childhood (Kusama 61-95). And whether she is really mentally ill has been much debated. Some speculate her "mental illness" might be a part of her publicity strategy - a known doubt well captured by a 2008 New York Times article's headline, "Is She Mad or Merely Cunning? While the Art World Debates, Yayoi Kusama Climbs Back on Top" (Worth). At any rate, however, it is truly "insane" that the artist has been living in a hospital voluntarily for over forty years. And notably, art historian Midori Yamamura's research into Kusama's personal documents, including hospital papers, has verified the artist's testimonials of strokes, suicide attempts, and therapy sessions during the 1960s as true facts. Based on an extensive archival research, Yamamura has convincingly argued that Kusama did not fabricate her mental illness, but formulated her lifelong psychiatric problems into a narrative during the 1960s, an action likely caused by her struggle for recognition. 
Besides her special talent in drawing and painting, Kusama had a rare ambition for success at a young age, which was what led her to travel alone to New York in the first place. Kusama was among the first Japanese artists to arrive on the contemporary art scene in New York City after World War II, and she recalls that her airplane cabin to Seattle (en route to New York) in 1957 was "empty except for two American GIs, a war bride, and me" (Kusama 11). It was very rare in the 1950s for a Japanese woman to not only travel abroad alone, but also to pursue a career outside domestic spheres.

Soon after arriving in New York in 1958, Kusama began to experiment with a new style of painting. In Japan she had earned recognition for her surrealistic watercolour and ink paintings, but in New York she began to create abstract monochrome oil paintings, known as Infinity Net series. She covered monumental canvases, as large as 33 feet long, with tiny arcs, nets and circles that she painstakingly painted day and night. The Infinity Net series can be seen as an outcome of Kusama's aspiration, critical savvy and sensitivity to the zeitgeist. Critically pondering the trends of the late '50s New York art scene, she said,

As for the art scene in the city at that time, the Action Painting of the New York School still held sway, even though Jackson Pollock had been dead for ten years. ... But ... It was clear to all that the New York School, which had prospered alongside the commercialization of art, now needed to break new ground (Kusama 34).

Kusama clearly saw the art world in both economic terms and historical contexts, and her Infinity Net paintings may have in fact targeted the New York art scene that continued to bask in the international success of Abstract Expressionism in seeming prolongation. Kusama's all-over abstract compositions evoke Jackson Pollock's drip paintings, but she filled her canvases with her own vision and subjectivity represented by the monochrome nets and dots. As her neighbour artist Donald Judd noticed, Kusama "was sophisticated about what had to be done as an artist for that time" (CICA vol. 36).

With the Infinity Net paintings, Kusama was indeed able to achieve her first solo show in New York, as early as October 1959, at the Brata Gallery. The show attracted much attention, receiving favorable reviews, excerpts of which Kusama proudly reprinted in her autobiography (24-34). It is important to note that these early reviews reveal the critical role Kusama's Japanese origins played in the New York audience's perception and evaluation of her work. The art critics tended to view her paintings as restrained Eastern derivatives of Abstract Expressionism. For example, Arts Magazine's Sidney Tillim compared her Infinity Net paintings to Jackson Pollock's 1946 Shimmering Substance, and said, "Conditioned by a tradition of not only black and white but of self-effacement, perhaps only a Japanese artist could create an art of withdrawal without the polemical emotions of Western Abstract Expressionism" (56). Donald Judd, then an Art News critic, wrote, "The expression transcends the question of whether it is Oriental or American. Although it is something of both, certainly of such Americans as [Mark] Rothko, [Clyfford] Still, and [Barnett] Newman" (17). These are no doubt favourable reviews, but the charged vocabulary of opposition-“Oriental" versus "American" and "Japanese selfeffacement" versus "polemical emotions of Western Abstract Expression" - hints at the EastWest dichotomy in the era's public discourses and the Western audience's preconceived expectations for a Japanese artist.

Despite critical acclaim of the Infinity Net paintings and her subsequent solo exhibitions, Kusama continued to struggle for recognition and survival: "The city was saturated with the possibility of great good fortune but also harbored a bottomless quagmire of shame and blame. And the heartless commercialism of many art dealers was too terrible even to joke about; it was a cause of real agony for many creative artists" (Kusama 37). At the time, Kusama was in fact searching in vain for an advocate in the commercial art scene. By the early 1960s, Pop art had emerged as the new, promising trend that would take American art's international success to the next level. And foreign artists like Kusama seemed to be losing opportunities while 
American artists such as Andy Warhol and Claes Oldenburg, with whom she used to exhibit in group shows, found representation with powerful art dealers such as Leo Castelli, Betty Parsons, or Charles Egan. In a letter written on September 9, 1963 to her Dutch artist friend Henk Peeters, Kusama complains about the monopoly of American Pop in the increasingly institutionalised New York art market: "By this American Pop [Americans] become exclusive of others" (CICA vol. 49). It should be highlighted here that Kusama compares Pop art to a nationalist American style. Similarly, artist Hans Haacke, a German-émigré working in New York since the 1960s, remembers the '50s and '60s as "a time when American artists developed national pride" (CICA vol. 35).

Ambitious and keen to succeed, Kusama sees herself as always ahead of the times, and since the 1960s has claimed that Warhol and Oldenburg, among other big-name American artists, stole her ideas to cement a legacy in the art history canon (Kusama 39-42). She asserts that her first three-dimensional production, a series of sewn phallic sculptures she began to make in the winter of 1961, were the original "soft sculpture," a practice widely associated with Oldenburg since 1962 (Turner 67). She also claims Warhol started to use repetitive imageswhich would become his trademark style-after seeing her collages filled with postage stamps and airmail stickers at Stephen Radich Gallery in the fall of 1961. When Warhol premiered his silkscreen 192 One-Dollar Bill in a Green Gallery group show in June 1962, their fellow artists also recognised an appropriation of a concept introduced previously by Kusama. Donald Judd "thought she should have gotten credit for this [use of repetitive imagery]" (Yamamura 81). Her neighbour artist Ed Clark remembers that Kusama around the time "suddenly got obsessed with the thought that her ideas might be appropriated, which compelled her to close all the curtains facing Park Avenue and 19th Street" (Yamamura 88).

In fact, in the early 1960s, Oldenburg and Warhol were leading artists in the emerging Neo-Dada and Pop art movements, whose practices were characterised by creative appropriation. These financially endowed art movements were promoted by the influential art dealer Leo Castelli. While the U.S. government during the Cold War expanded its political and economic power across the globe, Castelli built his own American art empire in New York, contracting male, American artists such as Warhol, Oldenburg, Robert Rauschenberg, and Jasper Johns. The culminating achievement of Castelli's entrepreneurial promotion occurred at the Venice Biennale. The 1964 grand prize was awarded to Rauschenberg, making him the first American artist to receive the prestigious award in 69 years of the Venice Biennale's history.

Kusama's desire for critical and commercial success was no secret among colleagues. Artists like Hans Haacke and Carolee Schneemann have commented on how Kusama in the 1960s was "very determined to make herself known" and "extremely desperate and increasingly ferocious trying to position her work" (CICA vols. 35 and 39). Arthur Lubow, who met Kusama in 2012 for a W Magazine interview, remarked with surprise how the 83-year-old artist, who was currently having a successful retrospective at Tate Modern, would periodically interrupt him to tell him how famous she was and to ask if he thought she was more famous than other artists of her generation.

I would argue that Kusama's obsession with recognition and acceptance should be considered in relation to her social position and identity in the 1960s, rather than her personal vices of narcissism, neurosis, or pathology, which have coloured perceptions of the artist and interpretations of her work. Her incessant emphasis on her own originality results from her marginalization in the New York art community during the '60s. In the 2008 documentary film sarcastically titled Yayoi Kusama: I Love Me, Kusama speaks directly to the camera: "I'm an excellent creator. I've always been a pioneer in my work. I'm filled with originality. I've never imitated other creators" (Yayoi Kusama). However, the seemingly arrogant proclamation is followed by a statement that subtly hints at the reason behind her egocentrism and narcissism: "Artists think their own pieces are the best, so we don't see things that way. We can't live if we don't believe ours are the best. You can't be an artist if you don't make up your mind that 'I'm 
the one who creates the best work"' (Yayoi Kusama). This confession suggests that her often criticised narcissism and obsession with fame reflect a naked vulnerability and gnawing fear of being marginalised and rejected.

\section{KASUMA's SELF-STYLISATION, SELF-DISPLAY, AND SELF-PROMOTION}

In 1963, amid her struggle with declining health and a flailing career, Kusama underwent a remarkable makeover, as if seeking to advance her career through self-display and self-promotion. A collection of snapshots titled "Yayoi Kusama: A Picture Biography" in a 2009 exhibition catalogue clearly show the chronological evolution of the artist's style (Diederichsen). At the beginning of her career, Kusama attended show openings wearing Western-style twopieced suits and with her hair pulled back in a tidy bun, thus looking like a neat professional woman. But in 1963, she began to appear in public events dressed in sumptuous kimonos, and changed her hairstyle to the "Cleopatra" coiffure, which had been recently popularised by Elizabeth Taylor starring as the exotic Egyptian queen in the 1963 movie. It was evident she had decided to exploit the commercial value of her "exotic" appearance in order to advance her career. "She used situations that she created. ... She appeared wearing a beautiful kimono, and she liked it," as her artist friend Henk Peeters remembers (CICA vol. 49).

It was also in 1963 that Kusama's earliest account of hallucination appeared. During her interview with the art critic Gordon Brown for WABC radio in 1963, she described how "My nets grew beyond myself and beyond the canvases I was covering with them. They began to cover the walls, the ceiling, and finally the whole universe" (Hoptman et al 100-105). This incident suggests that Kusama was at the time trying to publicly connect her artwork to her inner selfthus using her mental illness to draw attention not only to her work but also to her image. An archival research revealed that Kusama developed her story about her hallucinations into a written document in 1966 in New York with the assistance of two art critics, Jay Jacobs and Gordon Brown, who helped her translate, copyedit, and title it (Yamamura 64n8). Ten years later, the artist would officially publish an essay on her inner struggle, Waga Tamashii No Henreki To Tataki ("Odyssey of My Struggling Soul”), published in the Japanese art magazine Geijutsu Seikatsu in November 1975 (Hoptman et al 118-122).

In December 1963, moreover, Kusama opened an ambitious exhibition at the Gertrude Stein Gallery in New York titled Aggregation: One Thousand Boats Show-an impressive installation of a white rowboat bristling with a thousand sculpted fabric phalluses. The artist covered the gallery walls with 999 black-and-white photographic reproductions of the phalluscovered rowboat that she displayed in the corner of the room. More interestingly, however, during the exhibition Kusama produced a nude photograph of her, for the first time in her career. The black-and-white photograph of her standing naked in her phallic environment was not a snapshot; Kusama meticulously planned and staged the photo-shoot. She hired Rudolph Burckhardt, a photographer well associated with Abstract Expressionists, and directed him as to how best to compose the picture (Zelevansky 20). By directing the photographer, staging herself inside her installation art, and performing erotically for the camera, Kusama thus consciously turned herself into an art object to be looked at while also maintaining her role as the "author" and artist of the image. By hiring one of the best-known art magazine photographers, she aggressively embraced the commercial system of publicity photography under her own artistic practice.

Starting with this nude photograph, Kusama increasingly focused on staging herself in various environments, including urban streets, tabloid magazines and newspapers, and her own installations-which are all well documented in photographs. Thus she used her body as a medium of art and publicity. In the mid-1960s, she began to participate in the counterculture emerging in New York, organizing numerous naked body-painting performances (during which she painted dots on the participants' bodies) and flag-burning demonstrations with hippies. And in 1968-1970 she further involved herself with the underground cultural production, producing 
various business ventures, such as Kusama Fashion Company, Kusama Orgy weekly newspaper, and a homosexual social club called KOK.

These activities were largely ignored and rejected by the critics in the mainstream art community who had praised her previous work in painting and sculpture (Kusama 97). Even the relatively liberal underground art newspaper Village Voice harshly criticised her hippiestyle naked group performance on November 17, 1968 saying, "Kusama, whose gross lust for publicity never leaves room for taste, managed to put on the year's most boring freak shows ... Kusama is definitely suffering from over-exposure of over-exposure" (Solomon 100). In retrospect, however, the seemingly "non-artistic" activities can be understood as pioneering examples of the then emerging Performance Art and Pop Art movements. Kusama's contribution can be compared for example to Andy Warhol, who turned his studio into a social hangout and business enterprise known as the Factory. Extending art to encompass pop production, Warhol founded Interview magazine (in 1969), and discovered and managed celebrities like Nico and Edie Sedgwick, known as "Warhol Superstars." His famous public persona, widely recognised by his silver wig, striped T-shirt, and leather jacket, has been celebrated. Kusama, on the contrary, was reputed as being an exhibitionist and attention seeker-because she was a woman and non-white. As Carolee Schneemann, an artist regarded widely as a feminist pioneer of performance art, noted emphatically: "[Kusama] and I were the few female artists using the body, using nudity, and using the obsessive imagery.... Many times I had to fight for her, because her situation was much like mine. 'Oh, she's just nude,' and 'that Oriental nude running around'" (CICA vol. 39). It seems that accusations against Kusama's activities result in great part from the '60s sexist and racist backlash.

\section{KASUMA'S SELF-ORIENTALISATION AS CRITIQUE}

Kusama's public spectacles were seen as crude attention-seeking acts, but a close observation of her performances, particularly her kimonoed performances, reveals that they were more than a survival tactic, a performative critique of the Orientalist fantasy prevalent at the time. As mentioned, starting in the early 1960s she would often appear in gallery openings and other events, gaudily dressed in kimonos in obvious gestures to seek attention. But the artist also staged performance art pieces that used kimono as the costume, and it is in the latter cases that reveal her critical stance.

Kusama was well aware of the Orientalist fetishism about kimono and Japanese women as she was experiencing them directly in America and Europe. The longest romantic relationship she has had was with the American artist Joseph Cornell, whom she dated for about ten years before his death in 1972. Kusama claims that what sparked the ten-year affair was her exoticism and what she calls Cornell's "Lolita complex," which she associates particularly with notions of "Orientalism" and "Japanism" of the "50s and "60s (CICA vol. 5). Lolita Complex, more commonly known as "lolicon" in Japan, refers to a sexual attraction to teenage girls, usually by male adults. Kusama first met Cornell, twenty-six years her senior, in 1962 through an art dealer who hoped to win over the otherwise reclusive and obstinate man by enticing him with "an attractive Oriental girl," so Kusama wore "my finest kimono, with a silver obi" to accompany her to visit Cornell in Queens (Kusama 163). For Cornell it was love at first sight, and he began writing love letters (Kusama 166-169).

In the 1950s and 1960s, the American wars in Asia had resuscitated the pre-existing Orientalist visions of Asia and particularly Japan. During and after the U.S. Occupation of Japan (1945-1952), romance and marriage between American GIs and Japanese women occurred frequently and the so-called Japanese "war brides" gained a new visibility in America. In American culture, the image of kimonoed "geisha" women was also greatly popularised. Data shows that between 1949 and 1967, Hollywood produced over a dozen movies set in Japan, in addition to nearly two dozen war movies set in Asia (Shibusawa 256). They ranged from highbudget films like Sayonara (1957) starring Marlon Brando and The Barbarian and the Geisha 
(1957) starring John Wayne to B-movies like Japanese War Bride (1952) and Three Stripes in the Sun (1955). These movies commonly portrayed a sappy, interracial love affair between a Japanese/Asian woman and an American man, in which the woman is invariably depicted as loyal and submissive and always dressed in exotic traditional dresses that mark her ethnic difference. This is a familiar narrative in Western literary tradition, which can be traced to the famous opera by Giacomo Puccini, Madame Butterfly (premiered in 1904 in Italy), one of the last productions of European japonisme that boomed in the late nineteenth century.

Madame Butterfly became a sort of "prototype" of interracial romances that end with the non-white female protagonist's sacrifice (Marchetti 79). In the opera, Cio Cio San, nicknamed Butterfly, is a beautiful fifteen-year-old Japanese girl contracted to marry the American naval officer Pinkerton (who she subsequently falls in love with) during his sojourn in Nagasaki. After Pinkerton leaves for his home country, Butterfly waits loyally for his return, having given birth to their son. After three years, Pinkerton returns with his American wife, and the devastated Butterfly sends her little son to the American couple and kills herself. The same narrative is reiterated in numerous film and theatre adaptations, including a 1915 silent film starring Mary Pickford and a 1932 Paramount film featuring Cary Grant, and also in interpretations set in other Asian countries such as the popular Broadway musical Miss Saigon (1989). The longevity and international popularity of the narrative indicate vestiges of the imperial fantasy in modern Western culture.

Kusama parodied not only the Madame Butterfly narrative but also the Geisha Girl stereotype of Japanese women in her 1966 street performance titled Walking Piece. In the solo performance, the artist flamboyantly strolled the streets of Lower Manhattan, dressed in a blossoming pink floral kimono and carrying a matching umbrella. Thus performing a "geisha," she invited passers-by to indulge in latent Oriental fantasies. The performance was documented by Eikoh Hosoe in colour photographs, which evince that Kusama was playing a "geisha" as imagined and portrayed in Western fictions, not a traditional type of Japanese geisha. Specifically, it appears that the artist re-enacted emotional moments from Madame Butterfly: she wept, wandered dejectedly, and gazed longingly at the horizon of the Hudson River horizon as if waiting for her lover to return from across the Pacific. The "geisha" also appeared lost and misplaced in the industrial streets of Manhattan factory buildings, drug stores, and boulevards. Altogether the photographs evoke an image of a Western "geisha," which has no affinity with Japanese images of strolling women, for example ukiyo-e prints by the famous Edo-period artist Hokusai, in which the figures do not express much emotion and are situated in simple interiors or landscapes.

Kusama staged another kimonoed spectacle in 1966, at the 33 ${ }^{\text {rd }}$ Venice Biennale. Outside the prestigious international art exhibition's Italian Pavilion, she displayed Narcissus Garden, her installation piece consisting of 1,500 factory-made mirror balls, alongside a sign that read "Your Narcissism for Sale \$2", and sold the balls to the passers-by. Wearing an exotic kimono and a pretty smile, she was offering for sale not just the mirror balls, but also "Yayoi Kusama." The artist exhibited her beautiful kimono-clad body amidst the shiny mirror balls, thus marketing herself along with her art objects. When the police came and ordered her to stopbecause she had received a permission only to exhibit her art but not to sell it-Kusama instead passed out self-promotional flyers that featured the renowned art critic Sir Herbert Read's poetic description of her work as "images of strange beauty" that "press ... on our organs of perception with terrifying insistence" (Hoptman et al 63).

While this incident perfectly exemplifies Kusama's self-marketing effort-a taboo for an artist's work at the time-it is equally important to note that it was her "most straightforward critique thus far of the mechanization and commodification of the art market" (Hoptman 5051). The artist's act of mongering, bartering and selling transgressed the conventional code of conduct at the prominent international art exhibition. The title of the installation, Narcissus Garden, suggests that the artist wanted to parody the narcissism of the art collectors and other 
art-world authorities involved in the acts of trading art and producing meanings about "art," although she has never explained in detail her intensions behind the installation/wholesale/ performance. Notably, Kusama offered mass-produced mirror balls as "art," whose shiny surfaces would reflect back at the viewer his/her own narcissism - while she was notorious and criticised for her narcissism involved in her practice of nudity and self-publicity.

By analyzing Kusama's performative exposure as a parodic critique of Orientalism, we arrive at a new interpretation of her nude photographs as well. The aforementioned nude photograph taken in her Aggregation: One Thousand Boat Show, for example, can be interpreted as Kusama's parody of Oriental female nudes in the tradition of Western art. With her back turned toward the viewer, the naked artist strikes the classical Odalisque pose-an invention of imperial French art that is familiar to us from the nude paintings by Jean Auguste Dominique Ingres. Female slaves of an Ottoman sultan, odalisques became the objects of fantasy for European artists and collectors in the nineteenth century who preferred to see the women in reclining nudes awaiting the male gaze. In comparison, Kusama presents her naked body as part of the installation that she has created. Thus in this image, she is both the subject and the object of the art.

In another staged nude photograph dated to the ' $60 \mathrm{~s}$, Kusama appears prostrate on a phallus-covered sofa, with her body covered in her trademark polka dots. Her pose here is strongly reminiscent of Paul Gauguin's thirteen-year-old Tahitian lover portrayed in his 1892 painting Spirit of the Dead Watching, another product of the French colonial history. Gauguin is known to have found both artistic inspiration and sexual pleasure in the French colony in the Pacific Ocean, and the Spirit of the Dead Watching demonstrates his romantic view of the primitive culture: his envy mixed with fear of their spiritual ascendancy is expressed in his juxtaposition of the Tahitian girl and the figure of the ghost. In contrast, in Kusama's work, her aggressive, independent self-presentation commands full authority over such supernatural powers and inspirations. This nude photograph of Kusama is actually a work of photomontage which she made by combining her nude photograph by Hal Reiff with photographs of her artworks: Accumulation No. 2 sofa (1962), Infinity Net painting (circa 1959-61), and the macaroni floor from her installation Food Obsession (which premiered in her 1964 Driving Image Show at Castellance Gallery). This photomontage is therefore a collective theatre of her oeuvre thus far. Full of "Kusamas," it represents her world and her visions. In it, she presents herself as a self-pleasing and self-inspired artist.

\section{Conclusion: As DotTy as She CAN Be}

Starting with the observation that Kusama has a unique presence in contemporary art, we have seen how Kusama's work in performance and persona cultivation began from a struggle for survival in the New York art world. A close look at Kusama's personal history within the cultural history of the New York art world has shown that for Kusama art could never be separated from self-marketing or from life. While she is often criticised for her self-promotion, it was in fact the harsh realities of the Western art market that taught her to play with her "exotic" appearance and identity in order to promote artistic success.

Literature on Kusama's work of the 1960s proliferated only after the artist re-emerged on the international art scene in the 1990s. The art critics and scholars of the 1990s tended to analyse how Kusama's self-display photographs of the 1960s appeared to the post-modern and post-feminist eyes and minds of the 1990s, without a close investigation of the historical backgrounds of the photographs. A danger in such a method is that the "white" Western observer could ignore possible phenomenological problems resulting from Kusama's gender and racial identity, as it is different from his/her own. An extreme example comes from New Yorker's art critic Calvin Tomkins, whose article "A Doyenne of Disturbance Returns to New York" (1996) was published at a time when Kusama's self-display photographs were avidly contextualised as feminist gestures. Criticizing the lionizing trend and referring to Kusama's 
photomontage nude, he said, "Fair enough. Let's just note, though, that in a frequently published photograph for which Kusama posed in 1966 .... her expression does not exactly project defiance" (Tomkins 102). Evidently he ignored the extravagant explosion of polka dots on her body and could not see that Kusama was possibly mimicking an image and masquerading as a seductress.

In Mythologies (1957), Roland Barthes analyses the sport of wrestling as spectacle. In his analysis, the wrestlers make excessive gestures expected by the spectators, and these grandiloquent gestures have no meaning but are signs of the wrestler's awareness of being watched and of his power to create spectacular entertainment. In the case of Kusama's performance of spectacles, however, there has been a critical problem with the reception. The current paucity of writings on the politics of Kusama's identity, appearance and performance indicates that the spectators have not been able to read her excessive gestures as mere signs. They have probably perceived her Oriental body as an image rather than a performing subject. The artist's excessively "Japanese" and "erotic" gestures have instead been observed as natural and normal for a Japanese woman.

However, Kusama-and the way she lives, works, and exists in the world-continues to challenge our norms, expectations, and myths in subtle, interesting ways. She is one of the few female artists in history who have seen their career thrive in the mainstream art market and culture during her lifetime. The success of the "crazy Japanese woman" also contradicts the Western myth of genius as tragic hero, which in modern art history is usually associated with male artists, such as Vincent van Gogh or Jackson Pollock, who died young. On the contrary, Kusama is still active and prolific, at the age of 86, while living in a psychiatric hospital. Her persona, as a result, is one that both reflects and transgresses common stereotypes about legendary artists. It exists and operates by shuttling back and forth between the domains of fiction and non-fiction, art and life, typical and extraordinary-while dancing with their proximity and distance. In her autobiography's final pages, Kusama “identifies mortality as her latest and perhaps final theme" (Lee 47). Her goal is now to produce work "that will shine on after my death" (Kusama 238). And as always, she does not lack resolve: "And no matter how I may suffer for my art, I will have no regrets. This is the way I have lived my life, and it is the way I shall go on living" (Kusama 238). Over a decade has passed since she wrote those words, and she continues to work with the same passion and obsession.

\section{WORKS CITED}

Akcan, Esra. Architecture in Translation: Germany, Turkey, and the Modern House. Durham: Duke UP, 2012. Print.

Andy Warhol: The Complete Picture. Dir. Chris Rodley. BFS Entertainment \& Multimedia Limited. 2002. DVD.

Barber, Fionna. "Abstract Expressionism and Masculinity." Varieties of Modernism. Ed. Paul Wood. New Haven: Yale UP, 2004. 147-186. Print.

Barthes, Roland. Mythologies. Trans. Annette Lavers. London: Vintage, 2000. Print.

Becker, Howard S. Art Worlds. Berkeley: U of California P, 1982. Print.

Bourdieu, Pierre. The Field of Cultural Production: Essays on Art and Literature. Ed. Randal Johnson. New York: Columbia UP, 1993. Print.

Buskirk, Martha. Creative Enterprise: Contemporary Art Between Museum and Marketplace. New York: Continuum, 2012. Print.

Caves, Richard. Creative Industries: Contracts Between Art and Commerce. Cambridge, MA: Harvard UP, 2000. Print. 
Center for International Contemporary Arts, New York [CICA]. Interviews by Alexandra Munroe and Reiko Tomii. 1988-1989. The Historical Music Recordings Collection, the University of Texas Libraries, The University of Texas at Austin. Archival audio cassette tapes.

Cockcroft, Eva. "Abstract Expressionism, Weapon of the Cold War." Artforum 12.10 (June 1974): 39-41. Print.

Danto, Arthur. "The Artworld." The Journal of Philosophy 61.19 (Oct. 1964): 571-584. Print.

Diederichsen, Diedrich, et al. Yayoi Kusama: Mirrored Years. Rotterdam: Museum Boijmans van Beuningen / Dijon: Le Consortium. 2009. Print.

Dyer, Richard. The Matter of Images: Essays on Representation. London: Routledge, 1993. Print.

Gibson, Ann. Abstract Expressionism: Other Politics. New Haven: Yale UP, 1997. Print.

Goffman, Erving. The Presentation of Self in Everyday Life. New York: Anchor, 1959. Print.

Guilbaut, Serge. How New York Stole the Idea of Modern Art: Abstract Expressionism, Freedom, and the Cold War. Trans. Arthur Goldhammer. Chicago: U of Chicago P, 1985. Print.

Hauser, Arnold. The Sociology of Art. Trans. Kenneth K. Northcott. Chicago: U of Chicago P, 1982. Print.

hooks, bell. Black Looks: Race and Representation. Boston, MA: South End, 1992. Print.

Hoptman, Laura. "Down to Zero: Yayoi Kusama and the European New Tendency." Love Forever: Yayoi Kusama, 1958-1968. Eds. Lynn Zelevansky et al. Los Angeles: Los Angeles County Museum of Art, 1998. 42-59. Print.

Hoptman, Laura, et al. Yayoi Kusama. London: Phaidon, 2000. Print.

Horkheimer, Max, Theodor W. Adorno, and John Cumming. Dialectic of Enlightenment. New York: Continuum, 1993. Print.

Judd, Donald. "Reviews and Previews: New Names This Month," Art News 58.6 (Oct. 1959): 17. Print.

Jung, Carl Gustav. Two Essays on Analytical Psychology. Translated by R. F. C. Hull. New York: Meridian, 1956. Print.

Kozloff, Max. "American Painting during the Cold War" Artforum 11.9 (May 1973): 43-54. Print.

Kusama, Yayoi. Infinity Net: The Autobiography of Yayoi Kusama. Trans. Ralph McCarthy. English ed. Chicago: U of Chicago P, 2011. Print.

Lee, SooJin. "Seriously Dotty." Art in America 100.1 (Jan. 2012): 45-47. Print.

Leja, Michael. Reframing Abstract Expressionism. New Haven: Yale UP, 1993. Print.

Lubow, Arthur. "Fame Becomes Her." W Magazine (June 2012). Web. 9 Feb. 2015.

Marchetti, Gina. Romance and the "Yellow Peril": Race, Sex, and Discursive Strategies in Hollywood Fiction. Berkeley and Los Angeles: U of California P, 1993. Print.

Marcus, George E., and Fred R. Myers. "The Traffic in Art and Culture: An Introduction." The Traffic in Culture: Refiguring Art and Anthropology. Eds. George E. Marcus and Fred R. Myers. Berkeley: U of California P, 1995. 1-51. Print.

Marshall, P. David. "Introduction." The Celebrity Culture Reader. Ed. P. David Marshall. New York: Routledge, 2006. Print.

-----. "Persona Studies: Mapping the Proliferation of the Public Self." Journalism 15.2 (2014): 153-170. Web. 16 Mar. 2015.

Nixon, Mignon. "Posing the Phallus." October 92 (Spring 2000): 99-127. Print.

Pollock, Griselda. "Yayoi Kusama: Three Thoughts on Femininity, Creativity and Elapsed Time." Parkett 59 (2000): 107-23. Print.

Ratcliff, Carter. “Longo's Logos.” Artforum 28.5 (Jan. 1990): 105-110. Print.

Shapiro, David and Cecile. "Abstract Expressionism: The Politics of Apolitical Painting." Prospects 3 (1977): 175-214. Reprinted in Pollock and After: The Critical Debate, $2^{\text {nd }}$ ed. London: Routledge, 2000.181-196. Print.

Shibusawa, Naoko. America's Geisha Ally: Reimagining the Japanese Enemy. Cambridge, MA: Harvard UP, 2006. Print.

Solomon, Andrew. "Dot Dot Dot: Yayoi Kusama." Artforum 35.6 (Feb. 1997): 66-73, 100, 104, 109. Print.

Thumim, Janet. "'Miss Hepburn Is Humanized': The Star Persona of Katharine Hepburn." Feminist Review 24 (Oct. 1986): 71-102. Print. 
Tillim, Sidney. "In the Galleries." Arts Magazine 34.1 (Oct. 1959): 56. Print.

Tomkins, Calvin. "On the Edge: A Doyenne of Disturbance Returns to New York." New Yorker 7 Oct. 1996. 100-103. Print.

Toynyon, Evelyn. Jackson Pollock. New Haven: Yale UP, 2012. Print.

Trinh, T. Minh-Ha. When the Moon Waxes Red: Representation, Gender, and Cultural Politics. New York: Routledge, 1991. Print.

Turner, Grady. "Yayoi Kusama." Bomb 66 (Winter 1999): 62-69. Print.

Wolff, Janet. The Social Production of Art. New York: St. Martin's, 1981. Print.

SooJin Lee holds a Ph.D. in Art History, and is an Instructor in Art History, Theory, and Criticism at The School of the Art Institute of Chicago, Illinois. 